OSOBA I MIŁOŚĆ
Filozofia Chrzé́cijańska $\bullet$ Tom 11, Poznań 2014
Unimersytet im. Adama Mickiewicza w Poznaniu • Wrdziat Teologiczny

\title{
RYSZARD KOZŁOWSKI
}

Akademia Pomorska w Słupsku

Wydział Nauk Społecznych

Instytut Pedagogiki i Pracy Socjalnej

\section{Antynomie miłości - słabość i moc. Personalne konteksty miłości agape i jej antropologiczne konsekwencje}

\author{
Antinomies of Love - Weakness and Power. \\ Personal Contexts of Agape Love and Its Anthropological Implications
}

Papież Benedykt XVI swoją pierwszą encykliką pt. Deus caritas est ${ }^{1}$, ogłoszoną w 2005 roku, zainicjował kolejną dyskusję na temat miłości, a zarazem ukazał duchowe tło dla rozpoczynającego się pontyfikatu. Tezy zaprezentowane w Deus caritas est poszerzył o nowe konteksty i interpretacje, ogłaszając w roku 2009 kolejną encyklikę pt. Caritas in veritate ${ }^{2}$. Caritas in veritate - o czym informuje nas w podtytule - ukazuje specyfikę ludzkiego rozwoju w miłości i prawdzie. Dla człowieka XXI wieku z obu tekstów płynie wyraźny komunikat, by refleksja nad miłością prowadzona była w szerokim spektrum nie tylko egzystencjalnym, filozoficznym czy religijnym, ale aby brała pod uwage jeden z ważniejszych wskaźników miłości - prawdę. Choć Benedykt XVI wprost o tym nie mówi, a co można odnaleźć w metafizycznym przesłaniu jego tekstów, namysł nad miłością caritas i agape nie może stracić z oczu jeszcze innej perspektywy osoby $^{3}$.

Ujmując problem w ten właśnie sposób, wprowadzamy miłość w jej naturalny żywioł, którym jest osobowy świat człowieka, wraz z jego pragnieniami i marzeniami, z jego przeszłością i nadziejami na przyszłość, a zwłaszcza $z$ jego współczesną orientacją w świecie. Człowiek w swym osobowym wymiarze oka-

\footnotetext{
${ }^{1}$ Benedykt XVI, Deus caritas est, Rzym 2005.

${ }^{2}$ Tenże, Caritas in veritate, Rzym 2009.

${ }^{3}$ Por. M. Składanowski, Ciało - dusza - duch. Myśl Josepha Ratzingera na tle współczesnej antropologii, Warszawa 2013.
} 
zuje się nie tyle „czymś”, ile właśnie „kimś”, i na tym poziomie jego egzystencji miłość (i prawda) odgrywają znamienną i fundamentalną rolę - fundują jego bycie w sercu jego wyjątkowości i niezwykłości, jednostkowości i niepowtarzalności, dramatyczności i mistycznego milczenia, niezniszczalności i trwałości. $\mathrm{Z}$ jednej więc strony próbujemy uchwycić w człowieku to, co nieprzemijalne i wieczne, $z$ drugiej zaś, idąc za tym, co w nim niepoznane jeszcze i nieprzekazywalne, podejmujemy fascynującą przygodę duchową i intelektualną, by odegrać swą jedyną rolę $\mathrm{w}$ życiu, które otrzymaliśmy w darze.

Czy szczególnie istotną rolę odgrywa w nim miłość? W chwilach zatrzymania się i refleksji odpowiemy - „tak”, lecz w biegu życia ta sama miłość wymyka się poznaniu, nierzadko doświadczeniu, a stosunkowo często zostaje zmarginalizowana czy też wysunięta poza margines najbardziej znaczących nawet przeżyć na rzecz uczuć czy emocji, które giną z pola refleksji tak szybko, jak szybko się zjawiły. Niekoniecznie pozostawiają one po sobie zranienia bądź poczucie egzystencjalnej pustki czy bezsensu, niemniej wymagają od myślącego podmiotu, by zapytał sam siebie, czy rzeczywiście czuje się szczęśliwy i spełniony, czy czuje w sercu duchową radość. Miłość okazuje się wielobarwna i wielowymiarowa, chwilowa i wiecznotrwała, poszerzająca horyzonty wewnętrznego i zewnętrznego świata osoby, ale i niszcząca. Jednak w każdej z tych jej charakterystyk dostrzec możemy jeszcze jedną antynomię - moc i słabość. Na niej właśnie chciałbym się tutaj skoncentrować. I nie dlatego, że zdaje się, iż jest główną jej antynomią (analogicznie wolności czy wszelkiego dążenia do prawdy, dobra i piękna), lecz dlatego, iż zdaje się najbardziej pociągająca i urzekająca, że dość blisko pozwala poznawczo podejść do tego, co w niej najbardziej tajemnicze i niezwykłe, że bodaj najpełniej wyraża prawdę o samym człowieku - prawdę w ukrytej głębi jego własnego bytu.

Intelektualnym tłem, w którym podejmuję się badania i opisu jednej z wyraźniejszej i zarazem bardzo inspirującej antynomii miłości - mocy i słabości, są słowa zanotowane przez św. Pawła w 2 Kor 12,9: „Moc bowiem w słabości się doskonali”. Święty Paweł jest na tyle oryginalnym myślicielem i teologiem, że warto zwrócić na niego uwagę, gdy pragnie się zgłębić fenomen miłości agape, zarazem trzeba wziąć pod uwagę jego cechy osobowości, o ile tylko możemy je poznać i włączyć w tok rozwijanej narracji. Z punktu widzenia psychologii (C.L. Sigaud, W.H. Sheldon) św. Paweł to typ somatoniczny, któremu według hagiotypów odpowiada typ praksotoniczny, nie zaś agapetoniczny. Dla św. Pawła miłość agape jest więc nie tyle tym, co „dane”, ile tym, co „zadane”: Paweł „czyni” miłość, „,czyni” dzieła miłosierdzia. W tym świetle nieco głębiej możemy zrozumieć jego wyznanie, że „moc doskonali się w słabości”.

Nie bez znaczenia są także stosowane przez św. Pawła greckie terminy. Słowo dynamis (łac. virtus), które przetłumaczono jako 'moc', oznacza także 'potęgę', 'siłę', 'zdolność', 'możność', natomiast słowu słabość odpowiada gr. asthe- 
neia i oznacza: 'słabość', 'brak sił', 'utratę odwagi', 'bycie bez podpory' (łac. infirmitas - 'słabość', 'choroba', 'nieufność'). Święty Paweł zatem, gdy prezentuje model działania łaski, a pośrednio miłości, w istocie rzeczy koncentruje się na mocy dynamis, by ukazać drogę i sposób jej spełniania się, urzeczywistniania, czy - mówiąc językiem arystotelesowskim - aktualizowania. „Moc” to możność (dynamis, potentia), więc jest w stanie permanentnego niepokoju, twórczości, poszukiwania adekwatnego pola, by się w nim w pełni wyrazić. W cytowanym fragmencie tym ,polem” jest słabość (gr. asthenos). Sam termin asthenos wskazuje, że chodzi tu o jakiś rodzaj zaprzeczonej siły, ukrytej w tym, co zdaje się być małe, nędzne i marne. Jak widać, św. Paweł myśli antynomiami (antynomiami transcendentalnymi), gdzie jedna z wyróżnionych rzeczywistości (moc) zawiera się - paradoksalnie - w drugiej (słabość).

\section{MIŁOŚĆ - WYŁACZENIE I DEZINTEGRACJA}

Według Slavoja Žižka, słoweńskiego filozofa politycznego, chrześcijaństwo jest religią miłości. Wyznanie to nie jest prostą prowokacją, by z punktu miłości podejmować dialogi ekumeniczne czy apologetyczne, nie jest też teoretycznym zabiegiem, mającym przekonać czytelnika, że tak właśnie jest, ponieważ samo już objawienie chrześcijańskie, zarówno w Starym, jak i w Nowym Testamencie, przeniknięte jest treściami agapetycznymi i wyraźną teologią i antropologią agepetologiczną. I nie jest też argumentem tekst św. Pawła z 2 Listu do Koryntian, gdzie wypowiada inspirujące słowa na temat miłości agape. Idąc za Žižkiem i jego oryginalnymi interpretacjami istoty chrześcijaństwa, wskazuję raczej na miłość w jej funkcji nie tyle łączenia i integrowania, ile wyłączania i dezintegracji.

Zagadnienie to wykłada autor w dwóch tekstach zbioru esejów pt. Kruchy Absolut. Czyli dlaczego warto walczyć o chrześcijańskie dziedzictwo ${ }^{4}$. Każdy z przywołanych tekstów dotyczy analizowanej przez św. Pawła miłości agape. W pierwszym tekście Žižka (Struktura i jej Wydarzenie) znajdujemy kilka uwag na temat specyfiki chrześcijaństwa i wydarzenia wcielenia, które „rozbija” rzekomo ustabilizowane struktury egzystencjalne, społeczne, struktury, które obiecują rozwój i postęp, ale nie obiecują wieczności, a wręcz ją wykluczają, niszczą i unicestwiają. Ujmując rzecz na innym poziomie, ukazuje autor, że w istocie chodzi tu o napięcie między czasem a wiecznością. Pyta więc: jak możliwe jest pomyślenie wieczności w czasie, jakiego typu struktury czasowe (historyczne) rozbija wieczność? Žižek, poszukując rozwiązania dla antynomii czasu i wieczności, stwierdza, iż „«Wieczność» nie jest pozaczasowa w tym prostym sensie,

${ }^{4}$ S. Žižek, Kruchy Absolut. Czyli dlaczego warto walczyć o chrześcijańskie dziedzictwo, thum. M. Kropiwnicki, Warszawa 2009. 
że utrzymuje się p o z a czasem; jest raczej nazwą Wydarzenia lub Cięcia, które podtrzymuje, otwiera, wymiar czasowości jako serii/następstwa nieudanych prób uchwycenia go"5. Nie interesują go te koncepcje, które wykluczają Wieczność, aby doczesność (rzeczywistość historyczna) mogła zachować swoją spójność. Jego uwagę skupiają te ujęcia, które w doczesności „widzą” wymiar wieczności. Analogicznie do tego, jak w odrzuconym przez wspólnotę człowieku Chrystus „widział” to, co w nim najcenniejsze - że jest i kim jest. W tym sensie miłość wyłącza człowieka z bezmyślnej masy, z bezosobowego tłumu, dezintegrując tym samym skostniałe struktury myślowe i społeczno-polityczne.

Zdaniem Žižka, nie mają też swojej mocy religie przedchrześcijańskie, które, koncentrując się na mądrości, podkreślały jedynie „niewystarczalność każdego czasowego nieskończonego przedmiotu i nakazywały albo umiarkowanie w przyjemnościach [...] albo [nakazywały - RK] wycofanie z czasowej rzeczywistości na rzecz Prawdziwego Boskiego Obiektu, który jako jedyny może dostarczyć Nieskończonej Błogości”6. Po przeprowadzeniu kilku krytycznych refleksji zwraca uwagę na chrześcijaństwo, które „obstaje przy tym, że wiara w z a c ho $\mathrm{dza} c \mathrm{e}$ w c zasi e Wydarzenie Wcielenia jest jedyną drogą do wiecznej prawdy i zbawienia. Dokładnie w tym sensie - konkluduje - chrześcijaństwo jest «religią Miłości»", a w tejże Miłości „wyodrębnia się jeden skończony przedmiot, który «znaczy więcej niż cokolwiek innego»"8. Tym skończonym przedmiotem w perspektywie nieskończonej Miłości jest każdy człowiek, który zechce powiedzieć „tak” owej Miłości, który odważy się na przyjęcie Miłości jako wydarzenia zachodzącego w czasie, jednak mającego tę moc, by zmienić samą wieczność. Paradoks ten działa np. w wydarzeniu nawrócenia i przebaczenia.

Istotnego pogłębienia zaprezentowanych intuicji na temat antynomicznej struktury miłości agape dokonuje Žižek w kolejnym tekście zbioru (Chrześcijańskie odtaczenie). Nie wchodząc w zawiłą i specyficzną dla autora narrację, warto przyjrzeć się, w jaki sposób operuje on interesującym nas pojęciem. Nawiązując do $C z y$ nów mitości Sørena Kierkegaarda, „nienawiści ukochanego z miłości i w miłości”9 oraz do ewangelicznej zasady nienawiści rodziców w imię miłości, pyta: „,do nienawidzenia jakiego wy miaru w tym, kogo kocham, się mnie tu zachęca?”10. Miłość ma niespotykaną zdolność „odłączania” ze struktury społeczno-symbolicznej „,bezbronnego podmiotu”, miłość „widzi” niepowtarzalność osoby w powtarzalnych strukturach bytu ludzkiego. Mówiąc nieco inaczej, miłość aga-

\footnotetext{
5 Tamże, s. 103.

${ }^{6}$ Tamże, s. 104.

${ }^{7}$ Tamże.

${ }^{8}$ Tamże.

${ }^{9}$ Por. S. Kierkegaard, Czyny miłości. Kilka rozważań chrześcijańskich w postaci mów S. Kierkegaarda, tłum. A. Szwed, Kęty 2008, s. 120.

${ }^{10}$ S. Žižek, Kruchy Absolut..., dz. cyt., s. 134.
} 
pe, która odłącza szczegół od całości, chce widzieć osobę w tłumie bezimiennych jednostek, „,kogoś” pośród „innych”, wczuwa się w człowieka z jego najbardziej dramatyczną historią, by niejako „pod wydarzeniem” czy „wbrew niemu” ujrzeć prawdzie oblicze człowieka - zniszczone, stargane, poranione. W tym sensie miłość agape objawia swój antytotalitarny charakter.

Niekiedy „odłączenie” (wyłączenie) może kojarzyć się z ucieczką, ale w istocie nią nie jest - jest bezpośrednim wyrazem miłości charakteryzującym prawdziwego wyznawcę. O ile cynik przeocza ,skuteczność/rzeczywistość samego zjawiska bądź pozoru, bez względu na to, jak krótkotrwałe, kruche i ulotne ono jest"11, o tyle prawdziwy wyznawca ,dostrzega Dobroć w innym tam, gdzie sam inny nie jest jej świadom. [...] Kochająca osoba właśnie ufając zjawiskom [zachodzącym w czasie i przestrzeni - RK], widzi innego takim, jakim on lub ona naprawdę jest i kocha go lub ją właśnie za jej słabości, nie zaś pomimo nich"12.

Miłość agape nie daje się oderwać od Absolutu. Žižek, idąc za objawieniem wyrażonym w poszczególnych Listach św. Jana, pisze, iż Absolut

jest czymś absolutnie kruchym i ulotnym. [...] Czymś, co objawia się nam w ulotnych doświadczeniach - powiedzmy w miłym uśmiechu pięknej kobiety lub nawet w ciepłym, opiekuńczym uśmiechu osoby, która skądinąd może wydawać się brzydka i szorstka; w takich cudownych, ale skrajnie kruchych momentach przez naszą rzeczywistość prześwieca inny wymiar. Jako taki absolut szybko niszczeje, za szybko prześlizguje się nam przez palce i trzeba z nim obchodzić się delikatnie, jak $\mathrm{z}$ motylem ${ }^{13}$.

Do wiary w taki Absolut, w Absolut, który jest miłością (por. $1 \mathrm{~J} 4,16$ ), potrzeba miłości czułej i wrażliwej, mocnej i wytrwałej, a na pewno otwartej na Jego kruchość i przelotność. Czy nie taki właśnie Bóg (Theos) dla Arystotelesa był „Poruszycielem”, dla wielu proroków starotestamentalnych „Pocieszycielem", a dla św. Jana objawionym w Jezusie Chrystusie Logosem?

Czy św. Paweł pojmuje miłość agape jako ,samoznoszący się o bow i ąz e k kochania bliźniego i troski o niego, jako ci ężką p ra cę, jako coś dokonywanego przez żmudny wysiłek walki i hamowania swoich spontanicznych «patologicznych» skłonności"14 czy też jako objawienie się mocy w słabości, wieczności w tym, co ulotne jak trawa, „zalew wielkoduszności”, ,samopotwierdzająca się postawę”, „skromne dozowanie spontanicznej dobroci”? ${ }^{15}$. Jeśli postrzegamy moc i słabość, kruchość i wieczność jako antynomie jednej i tej samej miłości człowieka do człowieka, człowieka do Boga i Boga do człowieka, raczej

\footnotetext{
11 Tamże, s. 135.

12 Tamże.

13 Tamże, s. 135-136.

14 Tamże, s. 107.

15 Por. tamże, s. 108.
} 
nie pogubimy się w ustalaniu jej jednoznacznej formy, gdyż taka istnieje tylko w obszarze marzeń i iluzji ${ }^{16}$. Niekiedy człowiek przyjmuje taką fałszywą postać „miłości”, fałszywego „ubóstwienia”, jednak tutaj - trzeba dodać - mamy raczej do czynienia nie tyle z miłością, ile z jej imitacją i przewrotnym ubóstwieniem, które ,idealizuje, jest ślepe na słabość innego - lub jest raczej ślepe na innego jako taki e go, używając ukochanego lub ukochanej jako pustego ekranu, na który projektuje swoje własne fantasmagoryczne konstrukcje. Natomiast prawdziwa miłość akceptuje tego, kogo kocha, takim, jaki jest [...]"'17.

Miłość - kończy swoje rozważania Žižek - to raczej „dzieło miłości”, „czyn miłości” - „ciężka i mozolna praca polegająca na powtarzanym «odłączaniu»”, na zdobywaniu podmiotowości w zalewie przedmiotowości, na uchwytywaniu wyjątkowości w powszechności, mocy w słabości. Prawdziwa miłość pozwala zrozumieć wciąż uobecniającą się i doświadczaną antynomię słabości i mocy, które wyrażają jej najgłębszą istotę, majestat i wielkość.

\section{MIŁOŚĆ RESENTYMENTALNA}

Fryderyk Nietzsche w Antychrześcijaninie chce być prawdziwym apologeta chrześcijańskiej religii miłości, ale też i miłości samej. O jaką jednak „miłość” mu chodzi? Według Nietzschego miłość jest jedną z trzech, obok wiary i nadziei, chrześcijańskich roztropności.

Miłość jest stanem, w którym człowiek widzi rzeczy zwykle takimi, jakimi one właśnie nie są. Siła iluzji osiagga tu swe wyżyny, podobnie jak siła osładzania, rozpromieniania. W miłości można znieść więcej niż zwykle, miłość pozwala wszystko tolerować. Należało wynaleźć religię, w której można miłować: dzięki temu wychodzi się poza najgorsze strony życia - w ogóle się ich już nie widzi ${ }^{18}$.

W nawiązaniu do przywołanego fragmentu miłość nie godzi swych konstytuujących ją - z perspektywy chrześcijańskiej - antynomii mocy i słabości; miłość ma być mocą, a jeśli nią nie jest, jest fikcją, iluzją i złudzeniem. Miłość w tym rozumieniu - mówiąc słowami Gabriela Marcela - nie stawia czoła sytuacji, ale chce zwodniczo wyprowadzić człowieka poza sytuację. Czy jest to możliwe? Dla miłości posługującej się cnotą roztropności poniekąd jest to możliwe, lecz w tym wypadku nie mamy już do czynienia z miłością w sensie, który odsłaniali nam już starożytni Grecy czy potem samo chrześcijaństwo, a przede wszystkim jej

\footnotetext{
${ }^{16}$ Por. R. Kozłowski, Bóg - Człowiek, Człowiek - Bóg. Dylematy możliwej miłości, „Zeszyty Karmelitańskie" 1(62) 2013 styczeń-marzec, s. 30-36.

${ }^{17}$ S. Žižek, Kruchy Absolut..., dz. cyt., s. 136.

${ }^{18}$ F. Nietzsche, Antychrześcijanin, tłum. G. Sowiński, Kraków 1996, fr. 23; por. K. Jaspers, Nietzsche a chrześcijaństwo, thum. C. Piecuch, Warszawa 1991.
} 
nierzadko dramatyczną historią, kiedy to z miłości oddawano życie za drugiego, lecz z jej karykaturą. Choć Nietzsche wyraźnie uprzedza, że miłość należy do jednej z roztropności, to tym samym zatraca jej zbawienną dla człowieka moc i siłę, a drogi wyjścia z sytuacji widzi w tchórzliwej ucieczce. Wspaniałomyślność chrześcijańskiej roztropności polega na tym, że ,uzdalnia rozum praktyczny do rozeznawania w każdej okoliczności naszego prawdziwego dobra i do wyboru własnych środków do jej spełnienia. [...] Dzięki tej cnocie bezbłędnie stosujemy zasady moralne do poszczególnych przypadków i przezwyciężamy wątpliwości odnośnie do dobra, które należy czynić, i zła, którego należy unikać"19. Wkomponowana w miłość roztropność zdradza swój transcendentalny charakter i - ostatecznie oraz źródłowo - swe transcendentne pochodzenie, stając się kolejnym „narzędziem”, jeśli nie manipulacji sobą czy drugim człowiekiem, to ,zasadą sprytu”, zamiast - jak chciał choćby Žižek - ,zasadą życzliwości”.

Z Nietzscheańską interpretacją miłości rozprawia się Max Scheler w tekście pt. Moralność chrześcijańska a resentyment ${ }^{20}$. Zdaniem Schelera, tak jak dla chrześcijaństwa, nie jest ostatecznie istotne rozgraniczanie miłości agape, caritas, od erosa czy amora, gdyż rozumie się je jako wyraz jednej i tej samej miłości, wielorako ukierunkowanej i zdynamizowanej. W źródłowym rozumieniu agapiczny wymiar miłości oddaje to, co „wyższe” - jest czymś darowanym człowiekowi, a także to, co „mocniejsze” - boskiego pochodzenia, natomiast erotyczny aspekt miłości oznacza to, co „niższe” i z tego względu „słabsze” - co m.in. potrzebuje pomocy i uwznioślenia. O ile w modelu greckim najczęściej spotykamy dążenie od „niższego” ku „wyższemu”, od tego, co „słabe”, ku temu, „,co mocne”, od „mniej doskonałego” ku „bardziej doskonałemu”, o tyle w modelu chrześcijańskim następuje trudny do przyjęcia po dzień dzisiejszy ruch przeciwny: „miłość ma się przejawiać w tym właśnie, co nieszlachetne, zdrowy ku choremu, bogaty ku ubogiemu, piękny ku brzydkiemu, dobry i święty ku złemu i wulgarnemu, mesjasz ku celnikom i grzesznikom"21. Nietzsche, trzymając się greckiego modelu miłości, chce transponować go na model chrześcijański, stąd „miłość" mogła przyjąć tylko postać roztropności, nic więcej. Tym samym antynomia mocy i słabości, tego, co „wyższe”, wobec tego, co „niższe”, nie zostaje rozwiązana - miłość siłą rzeczy przechyla się na jedno skrzydło, tracąc z pola widzenia drugie ${ }^{22}$.

${ }^{19}$ Katechizm Kościoła katolickiego, Poznań 1994, nr 1805.

${ }^{20}$ M. Scheler, Resentyment a moralność, tłum. J. Garewicz, Warszawa 1977, s. 87-129.

${ }^{21}$ Tamże, s. 90.

${ }^{22} \mathrm{~F}$. Nietzsche analizę resentymentu włącza w szerszy kontekst refleksji na temat uczuć aktywnych i reaktywnych, analogicznie do „człowieka reaktywnego” i „,człowieka aktywnego”. Istotna moc człowieka aktywnego wywodzi się z uczuć aktywnych, jest twórcza i konstruktywna, w przeciwieństwie do uczuć reaktywnych, które leżą u podstaw działań destrukcyjnych. Tymcza- 
W krytycznym nastawieniu do spostrzeżeń Nietzschego trzeba powiedzieć, że antynomię słabości i mocy objaśnia właśnie model chrześcijański, który nie ma nic wspólnego z resentymentem jako z iluzją aksjologiczna, jak sugerował Nietzsche. Fałszywa „miłość”, u podstaw której leżałby resentyment, kierowałaby się jedynie własną, immanentną siła, zważającą na siebie samą, na własne projekty, tymczasem miłość prawdziwa jest ofiarna, to „pomoc, skłonienie się ku mniejszemu i słabszemu, jest spontanicznym kipieniem nadmiaru sił, któremu towarzyszy szczęście i pokój wewnętrzny" ${ }^{23}$. Mówiąc bardziej obrazowo: miłość kocha u chorego i ubogiego ,nie chorobę i ubóstwo, lecz to, co tkwi poza nimi w chorobie i ubóstwie niesie mu tylko «pomoc»"24. Miłość wspaniałomyślnie znajduje w słabym człowieku to, co jest mocne i zdrowe, kocha go w jego słabości i w chorobie, nie zaś pomimo nich. „Miłość” resentymentalna eksponuje słabość, mówi o niej, ale nie potrafi i nie chce jej zaradzić, aby niczego nie utracić z własnej, pozornej siły, każde zniżenie się traktuje jako własne poniżenie, by ostatecznie kierować się odwróconą postacią przykazania miłości - „będziesz nienawidził". Miłość chrześcijańska wywyższa się w pochyleniu nad potrzebującym. Nie jest zamaskowaną nienawiścią czy tłumioną zazdrością i zawiścią ukrywająca się pod upozorowanym altruizmem; nie zakłada masek, gdyż jako taka wydarza się w swoich aktach. Miłość pozorna szuka siły poza sobą, jest uwodzicielska i uwodząca, żeruje na tym, którego rzekomo kocha - kochany jest jej siłą.

Iluzoryczna „miłość” resentymentalna nie wyjaśnia zatem konstytutywnej dla miłości antynomii słabości i mocy, wybiera albo moc, albo słabość, nigdy moc ukrytą w słabości, to, co zdrowe, w tym, co chore, bogactwo w ubóstwie. Jest ślepa na inność, bo pozostaje wciąż zasklepiona w dusznym monolicie własnego bytu. Jej charakterystyką jest małoduszność, znudzenie drugim, brak żarliwości i niewdzięczność.

$\mathrm{Na}$ koniec swej wirtuozowskiej rozprawy Scheler zapytuje: w jaki sposób Nietzsche popadł w ten błąd i jak mógł przypisać tak wysoki stopień prawdopodobieństwa istnienia iluzji aksjologicznej, iż stać się mogła fundamentem moralności chrześcijańskiej? Scheler, pomijając mniej istotne objaśnienia, odpowiada tak, jak czyni to później Benedykt XVI w encyklice Deus caritas est. Obaj wskazują, że istotą wiary chrześcijańskiej jest „,chrześcijański obraz Boga i także wynikający z niego obraz człowieka i jego drogi”"25; że pierwszym powołaniem chrześcijanina jest to, że poznaje miłość, jaką Bóg ma ku niemu, i wierzy jej, co oznacza, że źródłem miłości chrześcijańskiej, źródłem chrześcijańskiego dyna-

sem miłość, wraz z widocznymi jej antynomiami, wymyka się zaproponowanej przez Nietzschego dialektyce - rozgrywa się bowiem w polu aktywności osobowej człowieka, w polu uczuć aktywnych. Por. F. Nietzsche, Z genealogii moralności, thum. G. Sowiński, Kraków 1997, s. 79 nn.

${ }^{23}$ Tamże, s. 95.

${ }^{24}$ Tamże, s. 99.

${ }^{25}$ Benedykt XVI, Deus caritas est, dz. cyt., nr 1. 
mizmu miłości jest Bóg, który pierwszy pokochał człowieka, człowiek zaś kocha innych tą właśnie boską miłością. Miłość jest wówczas tylko/aż odpowiedzią na ofiarowaną mu miłość, która równie wysoko podnosi człowieka. „U początku bycia chrześcijanina - zwraca uwagę Benedykt XVI - nie ma decyzji etycznej czy jakiejś wielkiej idei, ale natomiast spotkanie z wydarzeniem, z Osobą, która nadaje życiu nową perspektywę, a tym samym decydujące ukierunkowanie"26.

Poruszając się w tych kontekstach, trzeba wspomnieć o innej jeszcze antynomii miłości, na którą składają się przynajmniej dwa jej wymiary: miłość jako eros i miłość jako agape. I w tym momencie nie można zgodzić się na to, że eros jest jej słabością, a agape - mocą. Gra, jaka zachodzi pomiędzy nimi, i role, jakie ogrywają wobec siebie, wskazują na następujący fakt - podczas gdy jednym razem eros jako słabość i kruchość potrzebuje wzmocnienia ze strony agape jako mocy, to w innym przypadku agape jako ta „słabsza” i bardziej „krucha” oczekuje wzmocnienia i dopełnienia ze strony erosa. Agape odkrywa w erosie jego prawdziwą wielkość, hamuje jego dążenia do fałszywego ubóstwienia samego siebie, by ten mógł unieść człowieka ku „szczytom istnienia, tej szczęśliwości, do której dąży całe nasze istnienie"27. Eros ze swej strony widzi „słabości” wielkodusznej i wspaniałomyślnej agape. Agape, oderwana od erosa, pozostałaby oderwana od ,podstawowych relacji życiowych ludzkiego istnienia i stanowiłaby dla siebie odrębny świat, który mógłby być uważany jako godny podziwu, ale całkowicie odcięty od całości ludzkiej egzystencji”"28. Człowiek, dzięki kontemplacyjnemu uniesieniu się w miłości agape, może do głębi przejąć się potrzebami innych tak, by stały się jego własnymi. Kiedy „zstępuje” z poziomu miłości, agape może stać się „wszystkim dla wszystkich” (por. 2 Kor 12,2-4) 29.

\section{MIŁOŚĆ W ZWIERCIADLE WIARY I NADZIEI}

Spotkanie z Osobą stanowi istotę wiary chrześcijańskiej ${ }^{30}$. „Wiara polega na tym, że spotyka nas coś (ktoś), do czego nasza zdolność doświadczenia nie sięga sama z siebie. [...] Kategorie takie, jak «spotkanie», «odmienność» (Lévinas: altérité), «wydarzenie» charakteryzują duchowe początki wiary chrześcijańskiej

26 Tamże.

27 Tamże, nr 4.

28 Tamże, nr 7.

${ }^{29}$ Por. S. Kierkegaard, Czyny miłości. Kilka rozważań chrześcijańskich w postaci mów S. Kierkegaarda, dz. cyt., S. Kierkegaard, w rozdziale pt. Miłość nie szuka swego, na swój sposób objaśnia możliwość „,bycia wszystkim dla wszystkich”. „Miłość nie szuka swego - pisze - ponieważ w miłości nie ma nic mojego i twojego” (s. 259). Uwolnienie się od tego, co „moje” i „twoje” w miłości, tworzy przestrzeń bycia wszystkim dla wszystkich, z zachowaniem jednak autonomii bycia osobowego „Ja" i ,Ty”.

${ }^{30}$ Por. J. Ratzinger, Wiara - Prawda - Tolerancja. Chrześcijaństwo a religie świata, tłum. R. Zajączkowski, Kielce 2004, s. 72-73. 
i ukazują granice pojęcia «doświadczenia»" ${ }^{31}$. W zwierciadle tak pojętej wiary miłość osobowa znajduje dla siebie właściwą przestrzeń działania i dojrzewania - przyjmuje postać „tęsknoty” i „oczekiwania”, „samotności” i „obecności”, w każdym zaś wypadku jest pozytywnym i twórczym zwróceniem się ku drogiej Osobie i dobru, które ją stanowi. Ponieważ wiara nadaje życiu nowy fundament istnienia i życia, to miłość objawia człowiekowi, że jest nim właśnie Osoba, z którą wchodzi w zażyłe relacje. Nie jest ona tylko intencjonalnym zwróceniem się ku kochanemu i pożądanemu obiektowi, ale aktualnym życiem z nim i dla niego. Miłość zyskuje w ten sposób nowe sensy i nową treść - jest nią wiara. Miłość, poza tak rozumianą wiarą, pozostałaby absurdalną iluzją i wyrazem niespełnialnych marzeń osamotnionego człowieka.

W doświadczenie miłości wiara wnosi nowe rozumienie jej mocy i słabości. O ile w polu miłości możemy mówić o mocy, to jest to moc płynąca z wiary - od Osoby, jeśli zaś w polu miłości doświadcza się słabości, jest to nie tyle słabość tego, który jest kochany i który kocha, ile słabość jako „nieobecność”, jako „oczekiwanie” na spełnienie. Wiara jest także odpowiedzią na smutek i pustkę, które zagrażają miłości, które podważają jej wartość i sens, które chciałyby przekształcić ją w absurd i wzbudzić w oczekującym lęk, a nawet rozpacz.

Nowe oblicze miłości odsłania się wówczas, gdy analizujemy ją w zwierciadle nadziei. W nadziei miłość zyskuje swoje oryginalne ukierunkowanie na to, czego miłość jeszcze nie ma, a co nadzieja już ma. Miłość, ku której zmierza chrześcijańska nadzieja, „otwiera przede mną cały wszechświat, który dzięki miłości staje się «rajem»"32, otwiera to, przed czym zamyka człowieka zuchwałość i rozpacz. Wobec siły i wspaniałomyślności miłości obie te postaci zdrady nadziei uznać trzeba za jedne z bardziej niszczących go słabości i kruchości bytu, w które popadł w wyniku własnych decyzji i wyborów, w wyniku odcięcia się od jej źródeł. Miłość, szanując te wybory człowieka, konkretyzuje treść nadziei tak, że jest nie tylko zapowiedzią tego, co ma przyjść i co mogłoby się zdarzyć (co się już zdarza w nadziei), lecz kreśli przed zagubionym człowiekiem drogi wyjścia z opresji beznadziei, z uwikłania się w iluzoryczną wszechmoc własnego Ja. I takiej miłości człowiek może powiedzieć „nie”, ale nie może jej jako takiej zakwestionować i unicestwić, gdyż nie rodzi się ona z niego, lecz przychodzi z zewnątrz jako agape - jako miłość mu darowana.

Kto jest tym dawcą miłości? Ujmując rzecz z perspektywy chrześcijańskiej, trzeba powiedzieć, że pierwszym dawcą miłości jest Bóg, drugim - analogicznie - człowiek $^{33}$. Człowiek, „dając” miłość drugiemu, odkrywa, że w istocie party-

31 Tamże.

${ }^{32}$ J. Ratzinger, Patrzeć na Chrystusa, tłum. J. Merecki, Kraków 2005, s. 63.

${ }^{33}$ Miłość jest wartością, w której człowiek raczej uczestniczy, niż którą tworzy. Na ten aspekt wartości zwraca uwagę A. Siemianowski w swojej książce pt. Człowiek a świat wartości, Gniezno 1993, s. 93 nn. 
cypuje w miłości samego Boga, że on sam - jako istota stworzona - nie jest jej źródłem, lecz źródło jest poza nim, jednocześnie - i paradoksalnie - w nim: w duchowym wnętrzu jego osoby. Jeśli chce, prawdę tę może odkryć bez większych trudności.

W tym nastawieniu należy powrócić do uwag Schelera na temat idei Boga. $\mathrm{Na}$ wstępie trzeba powiedzieć, że jest ona czymś wyjściowym, co rzutuje dalej na ideę człowieka. Bóg - jak pisze Scheler - jest „Stwórcą przez miłość”, stworzył świat z „nieprzebranego nadmiaru miłości”, dlatego wart jest kontemplowania go, by tym samym nie pozostać obojętnym na jego losy, zwłaszcza na los samego człowieka; obojętność i pogarda rodzą się z kontemplacji samego siebie, uznania siebie za jedyne źródło wartości, a to jest właśnie istotą iluzji aksjologicznej, która ze stworzenia czyni bóstwo. Kontemplacja miłości Boga wyprowadza człowieka z okowów własnego Ja i zwraca ku drugiemu.

\section{OSOBOWA STRUKTURA MIŁOŚCI}

W świetle przeprowadzonych wyżej spekulacji poświęconych miłości natychmiast ujawnia się dylemat zawarty w redukcjonistycznych koncepcjach człowieka, które w żaden sposób nie radzą sobie z ujęciem i wyjaśnieniem zachodzących w niej antynomii - zwłaszcza antynomii słabości i mocy ${ }^{34}$. Przejdźmy zatem do zasadniczego pytania: jak moc może zbawić i ocalić słabość? Na jakiej mocy (zasadzie) słabość może wznieść się wzwyż albo to, co wyższe, mogłoby ogarnąć to, co niższe i słabsze? Nie chodzi oczywiście o proste pogodzenie dwóch wymiarów miłości, lecz o metafizyczną interpretację tej przestrzeni, w której słabość rodzi moc. Z perspektywy prowadzonego tu namysłu tą ,przestrzenią" jest osoba i jej struktura. W tym wypadku osoba oddaje swoją strukturę miłości, a miłość - osobie, zarówno w sensie epistemologicznym, jak przede wszystkim ontycznym.

Filozofia chrześcijańska najczęściej rozumie miłość przez dobro i wolę, widzi w niej konkretny czyn - „,czyn miłości” (Kierkegaard) oraz postawę. Święty Augustyn natomiast wiąże miłość z moralnością i interpretuje ją jako prawą wolę dobra. „Wola prawa - pisze w $O$ państwie Bożym - jest więc miłością dobrą, a wola przewrotna - miłością złą" "35. Już tu ujawnia się istotny jej rys - miłość jest ontycznym odniesieniem osoby „do” dobra, prawdy, do wartości, które właśnie ma przeżyć, którym udziela swojego bytu. Miłość uobecnia dobro i prawdę, a jeśli nie - jest pusta i bezwartościowa. Święty Tomasz, idąc po linii platońskiej, ujmuje miłość jako pragnienie dobra, dążenie do niego, upodobanie w nim, w in-

\footnotetext{
${ }^{34}$ Por. J. Pieper, O miłości, nadziei i wierze, tłum. I. Gano i K. Michalski, Poznań 2000.

${ }^{35}$ Św. Augustyn, O państwie Bożym, tłum. W. Kornatowski, Warszawa 1977, XIV, 7, 2, s. 129.
} 
nym zaś miejscu podkreśla jej aspekt społeczny (komunikacyjny). Miłość tworzy pewien związek uczuciowy pomiędzy kochającym a kochanym: „kochający uważa kochanego za w pewien sposób $\mathrm{z}$ nim złączonego lub do niego należącego, i stąd skłania się ku niemu"36, ale to nie wszystko.

$\mathrm{Z}$ personalistycznego punktu widzenia zagadnienie miłości rozpatrywane jest w kontekście relacji osobowych. Trudno więc zgodzić się na to, że miłość miałaby być tylko aktem, funkcją, czynem, działaniem lub postawą moralną, a nawet skłanianiem się ku drugiemu, jest bowiem jedną z głównych, jeśli nie główną strukturą świata osobowego, obok prawdy i czynu stanowi element konstytutywny osoby. W tym sensie można powiedzieć, że osoba jest „cała zbudowana z miłości, jest miłością i wyraża się przez miłość ad extra"37. Antyredukcjonistyczna interpretacja zagadnienia zwraca uwagę na fakt, że miłość jest

całoosobowym zwróceniem się istoty rozumnej i wolnej ku drugiej osobie i społeczności osób w celu spełnienia się we wszystkich aspektach. Jest to aktywność całej osoby, nie tylko przyzwolenie innym kochania nas (miłość bierna), ale aktualizacja całej naszej osoby i przedkładanie naszego ,ja”, duszy, umysłu, woli, energii uczuciowych, władz wykonawczych, działań - na aktywność absolutnie pozytywną względem drugiej osoby lub/i społeczności osób ${ }^{38}$.

Miłość ponadto odgrywa sobie właściwą i wyjątkową rolę w kształtowaniu tożsamości osobowej człowieka. W udzielonym mi wywiadzie, twórca personalizmu uniwersalistycznego, ks. prof. Czesław S. Bartnik, powiedział:

Miłość i wolność we właściwym znaczeniu mogą występować tylko w osobie i są formami jej realizacji, $w$ innych bytach występuja jedynie $\mathrm{w}$ dalekiej analogii. Wypełniają one podmiot osoby i dokonują jego tożsamienia się, ale zawsze w ścisłym związku z rozumem. Trzeba pamiętać, że we współczesnych kierunkach irracjonalnych rozum jest albo pomijany, albo spychany na dalszy plan. Miłość i wolność są to kategorie prapierwotne i trudne do pełnego oznaczenia. Stąd dzisiejsze kierunki łatwo sieją wielkie zamieszanie, absolutyzując je bez jednoczesnej precyzacji. Przede wszystkim nie precyzuje się ich stosunku do prawdy, a przez to i do norm etycznych. Tymczasem miłość i wolność są same z siebie ambiwalentne etycznie, a przez to realizują albo osobę albo antyosobę. Trzeba pamiętać - co jest pomijane - że miłość i wolność w dalekiej analogii występują także $\mathrm{w}$ różnych stopniach $\mathrm{w}$ bytach nieosobowych, nie tylko $\mathrm{w}$ świecie zwierzęcym i przyrodniczym (por. Empedokles z Agrygentu), lecz także w świecie materialnym, np. w świecie atomu, komórki, minerału itp. Toteż degeneracja miłości i wolności w człowieku pozbawia go a fortiori charakteru osobowego ${ }^{39}$.

${ }^{36}$ Św. Tomasz z Akwinu, Suma teologiczna, II-II, q. 27, a. 2, tłum. A. Głażewicz, Londyn 1967, s. 66; por. F. Sawicki, Bóg jest miłościq, Pelplin 2002, s. 30.

${ }^{37}$ C.S. Bartnik, Agapetologia personalistyczna, w: tenże, Kultura i świat osoby, Lublin 1999, s. 199.

${ }^{38}$ Tamże, s. 200.

${ }^{39}$ R. Kozłowski, O życiu i przeznaczeniu człowieka. Wywiad z ks. Prof. Cz. S. Bartnikiem. Roz- 
Bartnik jako personalista umieszcza miłość w strukturze osoby, a więc widzi ją jako to, co dane i zadane. Dane na poziomie duchowym, w relacji Boga i człowieka-osoby, w relacji socjologicznej człowieka do człowieka-jednostki, w relacji antropologicznej - umysłu i uczuć, woli i działań oraz do całej sfery wykonawczej, do której skierowane są własne myśli o miłości i uczucia miłości, skierowane do innej osoby, a także do zbiorowości, czyli do człowieka - afirmatywnego, aktywnie i intencjonalnie tworzącego relację osoby do osoby. Pierwszym imieniem osobowej miłości jest pokój, stan afirmatywnej równowagi - ,jak ty mnie, tak ja tobie; jak ja tobie, tak ty mnie". Jest to wyjątkowy stan ducha stan egzystencjalny, w którym brak innej osoby, deficyt innej osoby, a nawet strata staje się łaską. Zmusza osobę totalitarnie zorientowaną na własne Ja do wyjścia poza granice egoizmu, narcyzmu, autocentryzmu, w stronę utraconej relacji z Bogiem, którą zastapić może tylko inna osoba. I może zrobić to tylko wtedy, gdy tę relację odtwarza bezinteresownie, darmo, bez roszczeń do chwały Bożej, w zastępstwie Boga, a więc w stanie „łaski Bożej”. Kto to dziś potrafi?

W ujęciu Bartnika najważniejszymi składnikami miłości osobowej, czyli „osoby kochającej”, są rozumność, wolność i społeczność. A więc za miłość osobową nie można uznać relacji nierozumnej, nieświadomej, opartej na oczarowaniu, fascynacji czy na ogłupieniu zmysłów. To są tylko ramy miłości zmysłowej, która pojawia się i znika, oparta jest na chwilowych ekscytacjach, które z czasem gasną i znikają zamieniając się w stan rozczarowania i depresji. Tego rodzaju miłości czy paramiłości gatunek ludzki doświadcza najwięcej. Dlatego potrzeba dziś wielu klinik psychiatrycznych, które naprawiają błędne nauki o miłości człowieka, która utknęła w niemocy fizycznej czy psychicznej człowieka.

Jeszcze większym problemem niż przekroczenie cielesnych pułapek miłości jest przekroczenie jej pułapek wytworzonych przez ludzkie więzi, przywiązania, uzależnienia czy przymus (a także lęk przed samotnością), które stoją przed człowiekiem, gdy ten chce się oderwać od zmysłów i sądzi, że wystarczy mu, iż sam sobie będzie miłością, że sam się uwielbi i ubóstwi swoje Ja i swoje ciało, nazywając to wszystko - wolnością. Nic bardziej fałszywego. Wolność musi łączyć się z rozumnością i z miłością - najpierw w diady, a następnie w triadę, czyli we wspólnotę bycia z sobą, bez której wolność staje się zaprzeczeniem miłości, jej przeciwnikiem i wrogiem, który ginie pod naporem samotności, w życiu skierowanym do siebie, czyli do nikogo. Takie obsadzenie wolnego Ja przez siebie samo prowadzi do paranoi, która staje się maską wykluczonej z relacji miłości osoby do osoby.

Najgłębszym motywem i podłożem miłości jest wspólnota, dla niej się rodzimy, dla niej żyjemy i dla niej umieramy. Ona jest ziemskim substytutem Boga.

mawia ks. Ryszard Kozłowski, w: R. Kozłowski, T. Kobierzycki, F. Maj, Żyć. Myśleć. Wierzyć. O zwiqzkach filozofii i teologii w refleksji personalistycznej Czesława Stanisława Bartnika, Słupsk 2014, s. 55-56; por. I. Dec, Dlaczego miłość, Wrocław 1998, s. 81-96. 
Rodzina, klan, ród, naród, ludzkość są symbolami tego substytutu, dla którego sprawowana jest miłość człowieka, który czci rozmaite kręgi życia i śmierci. Wspólnota jest więzią żywych i umarłych, zbawionych i potępionych, której nie wystarczą ludzkie moce miłości. Do tego potrzebna jest moc Boga, który wszystko ożywia swoim tchnieniem, spojrzeniem, dotykiem i słowem. Wszystko byłoby martwe, gdyby nie było można pomyśleć miłości Boga, gdyby nie można było jej odczuć na tym padole prochów, cierpienia i łez, lecz nawet one stają się źródłami jego mocy otwartej i przelewającej się w eucharystycznym kielichu energii życia i miłości.

Antynomię słabości i mocy w miłości ostatecznie rozwiązuje osoba. Osoba jest zbawieniem i odkupieniem miłości w jej słabości, jest sakralizacją miłości w jej mocy. Miłość osobowa nie jest „relacją jednostronną, która pochłania drugiego, lecz przeciwnie - jest przeżyciem i relacją pomiędzy osobami, taką, która je wyodrębnia, esencjalizuje, wywyższa, a także wyzwala”40. Słabość „uwięziona” w sobie samej jako „odcięta” od życiodajnych i rozwojowych źródeł, jakie otrzymuje ze strony mocnej i wielkiej miłości, staje się patologią słabości. Z drugiej strony moc pozostawiona sobie samej, ,zakleszczona” w swojej tylko wielkości, pomijająca to, co kruche i słabe w człowieku, i w rzeczywistości jedynie udająca mocną i silną - tworzy jedynie patologię mocy. Osoba, ponieważ nie dzieli ludzi na słabych i mocnych, wytrąca $z$ tej pseudorównowagi miłość w jej słabości i mocy, z bałwochwalstwa, w którym czyni siebie bóstwem. Moc (gr. dynamis) doskonali się $\mathrm{w}$ słabości jedynie w horyzoncie osobowym. Osoba w danym momencie poddaje się słabości bądź mocy, przegrywa lub zwycięża, kocha $\mathrm{i}$ jest kochana; ona jest tym, co jest, jeśli wszystko już przeminie.

\section{BIBLIOGRAFIA}

Bartnik C.S., Agapetologia personalistyczna, w: tenże, Kultura i świat osoby, Lublin 1999, s. $187-206$.

Benedykt XVI, Caritas in veritate, Rzym 2009.

Benedykt XVI, Deus caritas est, Rzym 2005.

Dec I., Dlaczego miłość, Wrocław 1998.

Jaspers K., Nietzsche a chrześcijaństwo, tłum. C. Piecuch, Warszawa 1991.

Katechizm Kościoła katolickiego, Poznań 1994.

${ }^{40}$ T. Kobierzycki, Osoba. Dylematy rozwoju, Bydgoszcz 1989, s. 195. 
Kierkegaard S., Czyny miłości. Kilka rozważań chrześcijańskich w postaci mów S. Kierkegaarda, tłum. A. Szwed, Kęty 2008.

Kobierzycki T., Osoba. Dylematy rozwoju, Bydgoszcz 1989.

Kozłowski R., Bóg - Człowiek, Człowiek - Bóg. Dylematy możliwej miłości, „Zeszyty Karmelitańskie" 1(62) 2013 styczeń-marzec, s. 30-36.

Kozłowski R., Kobierzycki T., Maj F., Żyć. Myśleć. Wierzyć. O zwiqzkach filozofii i teologii w refleksji personalistycznej Czesława Stanisława Bartnika, Słupsk 2014.

Nietzsche F., Antychrześcijanin, tłum. G. Sowiński, Kraków 1996.

Nietzsche F., Z genealogii moralności, tłum. G. Sowiński, Kraków 1997.

Pieper J., O miłości, nadziei i wierze, tłum. I. Gano i K. Michalski, Poznań 2000.

Ratzinger J., Patrzeć na Chrystusa, thum. J. Merecki, Kraków 2005.

Ratzinger J., Wiara - Prawda - Tolerancja. Chrześcijaństwo a religie świata, thum. R. Zajączkowski, Kielce 2004.

Sawicki F., Bóg jest mitościq, Pelplin 2002.

Scheler M., Resentyment a moralność, thum. J. Garewicz, Warszawa 1977.

Siemianowski A., Człowiek a świat wartości, Gniezno 1993.

Składanowski M., Ciało - dusza - duch. Myśl Josepha Ratzingera na tle współczesnej antropologii, Warszawa 2013.

Św. Augustyn, O państwie Bożym, thum. W. Kornatowski, Warszawa 1977.

Św. Tomasz z Akwinu, Suma teologiczna, II-II, q. 27, a. 2, tłum. A. Głażewicz, Londyn 1967.

Žižek S., Kruchy Absolut. Czyli dlaczego warto walczyć o chrześsijańskie dziedzictwo, thum. M. Kropiwnicki, Warszawa 2009.

\section{SUMMARY}

The issue of love: eros and agape, enriched by its praxeological dimension of caritas, is engaging as it concerns life, development, and above all the personal identity of each person. This topic was clearly highlighted by Plato in his teaching and also presented today by Benedict XVI in his encyclical Deus Caritas Est. In this study Antinomies of Love - Weakness and Power, I show personal contexts in which love is present, and at the end I focus on anthropological and cultural consequences of using such model of interpretation. Most important, however, is that love is understood in the personal area of human existence. This makes it possible to get out of love new contents and meanings.

\section{Keywords}

love, antinomy, person, personalism, disintegration, resentment

\section{Słowa kluczowe}

miłość, antynomia, osoba, personalizm, dezintegracja, resentyment 